\title{
Metal and Phosphorus Uptake by Spontaneous Vegetation in an abandoned iron mine from a Semiarid Area in Center Morocco: Implications for Phytoextraction
}

\author{
Mohamed Nouri ${ }^{1}$, Fernando Gonçalves ${ }^{2}$, Jausé Paulo Sousa ${ }^{3}$, \\ Jörg Römbke ${ }^{4}$, Mohamed Ksibi ${ }^{5}$, Ruth Pereira ${ }^{6}$ and Abdelmajid Haddioui ${ }^{*}$ \\ ${ }^{l}$ Laboratory of management and valorization of natural resources, Team of Genetic and Plant Biotechnology, \\ Faculty of Science and Techniques, University of Sultan Moulay Slimane, Beni-Mellal, Morocco \\ ${ }^{2}$ CESAM \& Department of Biology, University of Aveiro, Campus Universitário de Santiago, 3810-193 Aveiro, \\ Portugal \\ 3 IMAR-CMA, Department of Life Sciences, University of Coimbra, 3004-517 Coimbra, Portugal \\ ${ }^{4}$ ECT Oekotoxikologie GmbH, Flörsheim, Germany \\ ${ }^{5}$ Laboratory of Water, Energy and Environment, University of Sfax, Tunisia \\ ${ }^{6}$ Department of Biology of the Faculty of Sciences of the University of Porto, Porto \& CESAM, University of \\ Aveiro, Portugal \\ * Corresponding author. E mail: ahaddioui@yahoo.fr; Tel: +212661684239
}

cross $^{\text {ref }}$ http://dx.doi.org/10.5755/j01.erem.64.2.3866

(received in March, 2013, accepted in June, 2013)

Spontaneously growing native plants (belonging to 12 species, 10 genera, and 3 families) were analyzed to study the accumulation of $\mathrm{Cd}, \mathrm{Cr}, \mathrm{Cu}, \mathrm{Zn}, \mathrm{Pb}, \mathrm{Fe}$ and $\mathrm{P}$ in shoots and roots. The different plant species collected in Ait Amar iron mining site exhibited large differences in shoot and root accumulation of metals. Among the grass species (Apiaceae, Asteraceae and Poaceae), the highest shoot $\mathrm{Cd}, \mathrm{Cu}, \mathrm{Zn}$ concentrations were found in Echinops spinosus L $\left(0.989,29.190\right.$ and $175.347 \mathrm{mg} \mathrm{Kg}^{-1}$ respectively), Cr in Cladanthus arabicus (L) Class $\left(9.241 \mathrm{mg} \mathrm{Kg}^{-1}\right.$ ) and $\mathrm{Pb}, \mathrm{Fe}$ and $\mathrm{P}$ in Leontodon hispidilus (Delile) Boiss (5.952, 1522.839 and $4612.795 \mathrm{mg} \mathrm{Kg}^{-1}$ ). The highest bioconcentration factors (BCF) were recorded for E. spinosus $L$ and $\mathrm{Zn}$ (1.68). The highest soil-plant transfer factor (TF) of Cd was 1.24 (Stipa Capensis thumb), of Cr was 2.01 (C. arabicus $(L)$ Class), of $\mathrm{Cu}$ was 8.40 (Carthamus lanatus $L$ ), of $\mathrm{Zn}$ was 2.52 (E. spinosus $L$ ), of $\mathrm{Pb}$ was 7.00 (Eryngium ilicifolium Lam), of $\mathrm{P}$ was 537.72 (E. ilicifolium Lam) and of $\mathrm{Fe}$ was 0.52 (L. hispidilus (Delile) Boiss). E. spinosus $L$ showed the highest $Z n$ phytoextraction capacity and other plant species demonstrated to grow well in metal contaminated soil taking up only low concentrations of metals, and, therefore they are good candidates for phytostabilization.

Keywords: mining site, bioaccumulation, native plants, $B C F, T F$.

\section{Introduction}

Heavy metals are significant environmental pollutants, and their toxicity is a problem of increasing significance for ecological, evolutionary, nutritional and environmental reasons (Nagajyoti et al. 2010). Mining is known to being one of the primary sources of metal pollution (Wei and Zhou, 2008) and generate a large amount of tailings that are generally deposited upon the ground surface. Tailings usually provide an unfavorable substrate for plant growth because of their low $\mathrm{pH}$, high concentrations of toxic metals and low nutrient content (Ha et al. 2011).

Various physicochemical methods for remediation of heavy metals from the terrestrial and aquatic environment are not feasible due to energy intensive and cost expensive (Horsfall and Abia, 
2003). Hence, there is an urgent need of some biological treatment system, which could replace these traditional treatment systems. Phytoremediation techniques are now considered to be promising alternatives to conventional techniques for the remediation of diffused or moderately contaminated soils (Díez Lázaro et al. 2006; Chehregani et al. 2009). Plants have the ability to accumulate metals such as $\mathrm{Fe}, \mathrm{Zn}$ and $\mathrm{Cu}$, that are essential for their growth and development, but only certain plants encompass the ability to gather heavy metals (Lasat 2002). It is important to use native plants for phytoremediation because such plants respond better to the stress conditions at the site than would plants introduced from other environments (Yoon et al. 2006).

In the past few years, an increased awareness of the importance of metallophyte biodiversity has emerged in the scientific community (Barrutia et al. 2011). Natural variation occurs in the uptake and distribution of essential and nonessential trace elements among crop species and among cultivars within species (Grant et al. 2008). Plants growing on contaminated soils respond to elevated concentrations of heavy metals in the soil to varying extents, depending on the total soil metal concentrations, soil physicochemical conditions (especially $\mathrm{pH}$ ) and the cultivars of plant (Wu and Zhang, 2002; Alexander et al. 2006). The spontaneous plant colonization in mine tailings is usually slow since the physicochemical characteristics of these sites are not suitable for most of the plant species (Conesa and Faz 2011). Nevertheless, some of the tolerant plant species can spread easily in these environments due to the lack of competitors (Conesa and Faz 2011).

The identification of plant species able to accumulate metals in their tissues represents an important strategy for the remediation of heavy-metal polluted sites, demonstrates that plants have the genetic potential to clean up contaminated soil. Phytoremediation is a subject of public and scientific interest and a topic of many researches (Raskin et al. 1997; Horsfall and Spiff, 2005; Igwe and Abia, 2006; Chehregani et al. 2009). An efficient approach to identify tolerant plants is the isolation of species growing in those contaminated soils or water bodies.

Phytoremediation is a cost-effective technology for environmental cleaning, if native plants were applied in each polluted areas. We need new and variable accumulator plants for phytoremediation in different climates, thus new studies are still necessary to find new accumulator plants for being used in different conditions. In this study, we investigated the concentrations, translocation and bioconcentration factors of toxic metals $(\mathrm{Cd}, \mathrm{Cr}, \mathrm{Cu}, \mathrm{Zn}$ and $\mathrm{Pb}), \mathrm{Fe}$ (the mine of iron) and $\mathrm{P}$ (the region rich with natural phosphate) of 12 plant species that were grown in the abandoned polluted sites of an iron mine (Oued Zem, Morocco) with the objective (1) to get a better knowledge of the accumulating capacity of 12 plant species, of $\mathrm{Cd}, \mathrm{Cr}, \mathrm{Cu}, \mathrm{Zn}, \mathrm{Pb}, \mathrm{Fe}$ and $\mathrm{P}$, and (2) to evaluate the potential use of these plant species for phytoremediation (phytoextraction, hytostabilization).

\section{Materials and Methods}

\subsection{The studied area}

The iron deposit of Ait Amar (33 $04^{\prime} \mathrm{N} ; 6^{\circ} 38^{\prime}$ $\mathrm{W})$, as part of the anticlinorium khouribga-Oulmes, is in the Hercynian Central Massif. The latter is the vast plateau, which occupies the northern part of the western Moroccan Meseta. The Hercynian Central Massif consists mainly of Paleozoic terrain ranging from Ordovician to Carboniferous, organized into a series of anticlinoria and synclinoria, general orientation NE-SW, and Hercynian granitic intrusions intersected.

The iron mineralization occurs as two lenticular layers of iron Oolitic intersperse throughout this set sandstone, whose capacity is estimated (1000 to 1500 $\mathrm{m})$. The mineralized layer starts with a black chloritic schist. This deposit, operated between 1937 and 1962 by the Moroccan society Mining and Chemicals (SMMPC), produced about 6 million tons of ore. This operation, done in its career and partly underground, has ceased, firstly by lack of opportunity, low Fe content (between 43 and 47\%) and high silica (12 to $17 \%$ ) and Alumina (8\%), secondly, due to high operating costs (passing from the extraction in discovery to underground extraction in 1957).

Inside the perimeter containing an exploitable potential (226 ha), resources are estimated at 86 million tons of ore at $43 \%$ of $\mathrm{Fe}, 16 \%$ of $\mathrm{SiO}_{2}$ and $0.7 \%$ of $\mathrm{P}$ with an average capacity of the mineralized layer of $10.5 \mathrm{~m}$. However, as with other Oolitic iron deposits of Morocco, the high silica content restricts the marketing of their ores. It is worth noting that the company operated under very adverse consequences: a lack of mechanization (crushing, loading and slaughter), many and unstable worker staff and high transport price. The combination of these factors led to the closure of the mine in 1963-1964 (Department of Energy and Mining, Regional Directorate Beni Mellal).

\subsection{Soil Physicochemical Characterization}

Because polluted sites are often of a highly heterogeneous composition, a systematic sampling was designed. The studied area was divided into four transepts (T.1.1, T.2.1, T.3.1 and T.4.1) (Table 1). Soil samples $(0-20 \mathrm{~cm}$ depth) were collected on 19 July, 2010. The samples were sieved to $2 \mathrm{~mm}$ and subjected to chemical characterization. Soil pH $(\mathrm{KCl})$ values were measured in a $1 / 5$ extraction ratio (sample/1 M KCl) after shaking for 15 minutes and left to settle for 30 minutes. Total organic carbon (TOC) was analyzed by dichromate oxidation and titration with ferrous ammonium sulphate (Walkley and Black, 1934). TKN was determined by the 
Kjeldahl procedure. Soil $\mathrm{pH}\left(\mathrm{H}_{2} \mathrm{O}\right)$ and conductivity were measured in a soil-water suspension $(1: 5, \mathrm{w} / \mathrm{v}$ extraction ratio) according to the method described in

FAOUN (1984). Soil moisture was determined by oven drying at $105^{\circ} \mathrm{C}$ for 24 hours.

Table 1 Description of the study site in the Oued Zem region of center Morocco

\begin{tabular}{||c|c|}
\hline Sample code & UMT coordinates \\
\hline T.1.1 & 29S 720066 3661172 \\
\hline T.2.1 & 29S 720014 3661211 \\
\hline T.3.1 & 29S 719983 3661228 \\
\hline T.4.1 & 29S 719992 3661144 \\
\hline
\end{tabular}

\subsection{Total and bioavailable metal concentrations}

Concentrations of total metals were determined by inductively coupled plasma atomic emission spectrometry ICP-AES after digestion of the samples. $2 \mathrm{~mL}$ of concentrated $\mathrm{HNO}_{3}$ were added to $150 \mathrm{mg}$ of soil samples, and mixed. The samples were then heated on a hot plate at $100{ }^{\circ} \mathrm{C}$ until dryness. After this, $3 \mathrm{~mL}$ of concentrated $\mathrm{HF}$ were added to the Teflon vessels and heated at $140{ }^{\circ} \mathrm{C}$ for 15 hours at the minimum (vessels closed). After cooling the vessels were opened and heated until dryness at 110 ${ }^{\circ} \mathrm{C}$. $2 \mathrm{~mL}$ of concentrated $\mathrm{HNO}_{3}$ were added and heated $\left(110^{\circ} \mathrm{C}\right)$ until dryness, this step was repeated, and the fifth time of dryness was got with $2 \mathrm{~mL}$ of concentrated $\mathrm{HCl}$ and $120^{\circ} \mathrm{C} .25 \mathrm{~mL}$ of $2 \mathrm{M} \mathrm{HCl}$ were added and heated for 2 hours at $100{ }^{\circ} \mathrm{C}$ and the vessels were closed. After cooling and filtration, all samples were analyzed for $\mathrm{Cd}, \mathrm{Cr}, \mathrm{Cu}, \mathrm{Pb}, \mathrm{Zn}, \mathrm{Fe}$ and $\mathrm{P}$ by ICP-AES using a Jobin Yvon ULTIMA 2 apparatus (the National Centre for Scientific and Technical Research (NCSTR), Rabat, Morocco).

Metal bioavailable (mobile) fraction determined using the $0.01 \mathrm{M} \mathrm{CaCl}_{2}$ extraction procedure (Gupta et al. 1996) and sometimes this method referred as the "effective bioavailable metal fraction" (Alvarenga et al. 2009). From the experience obtained by Pueyo et al. 2004, the $0.01 \mathrm{M} \mathrm{CaCl}_{2}$ extraction procedure seems to be a suitable method for the determination of $\mathrm{Cd}, \mathrm{Cu}, \mathrm{Pb}$, and $\mathrm{Zn}$ mobility in soils, since this procedure presents an appropriate extraction capacity for this type of studies and also uses the lowest salt concentration. This fact simplifies the matrix of the extracts and facilitates the metal determination with analytical techniques, such as ICP-AES. Soil $0.01 \mathrm{M}$ $\mathrm{CaCl}_{2}$ soluble trace element concentrations were determined in $1 / 10$ ratio, soil $/ 0.01 \mathrm{M} \mathrm{CaCl}_{2}$ extracts, (Houba et al. 1990; NEN 5704, 1996). After shaking for $2 \mathrm{~h}$ on a tabletop shaker, extracts were decanted and $60 \mathrm{~mL}$ were centrifuged $(2000 \mathrm{xg})$, and metal concentrations were measured by ICP-AES (NCSTR, Rabat, Morocco).

The plants reflecting most of plant biodiversity of herbaceous and shrub species present in the studied area were selected (07 May 2010). Plant samples were gently uprooted, taken to the laboratory, thoroughly washed with tap water in order to remove any surface soil or dust deposit, and then rinsed twice with distilled water and then separated into roots and shoots. Shoot and root dry biomass of each species was obtained after oven drying plant samples at $80{ }^{\circ} \mathrm{C}$ for 24 hours. Subsequently, plant samples were ground into fine powder. For total metal concentrations in the plant components, $1 \mathrm{~g}$ of plant samples were digested using nitric and hydrochloric acids. The sample was diluted to $100 \mathrm{~mL}$ and analyzed for total $(\mathrm{Cd}, \mathrm{Cr}, \mathrm{Cu}, \mathrm{Zn}, \mathrm{Pb}$ and $\mathrm{Fe})$ and $\mathrm{P}$ by ICP-AES using (USEPA Method 3050) (NCSTR, Rabat, Morocco).

A bioconcentration factor for soil (BCF) is defined as the metal concentration in dry shoot plant tissue / metal concentration in soil quotient (Mattina et al. 2003, Ha et al. 2011). A transfer factor (TF), or also called translocation factor (Mattina et al. 2003, Ha et al. 2011), is the ratio between the concentration of metals in shoots and roots and defines the effectiveness of the plant to translocate the metals to the shoots.

Statistical analyses of experimental data were performed using the SPSS 17.0 package for Windows. Kruskal-Wallis and Pearson correlation tests were used to detect significant differences in plant concentrations of heavy metals and between plant roots and shoots. Statistical significance in this analysis was defined at $\mathrm{P}<0.05$ and $\mathrm{P}<0.01$.

\section{Results and discussion}

\subsection{Characterization of the soils}

As expected, soil properties and chemical composition depended upon the geological material from which the soil was derived (Table 2). Substrate $\mathrm{pH}$ affects plant growth mainly through its effect on the solubility of chemicals, including toxic metals and nutrients. It is commonly recognized that at $\mathrm{pH}=6.5$, nutrient availability to plants is at a maximum and toxicity is at a minimum (Harris et al. 1996; Wong, 2003; Freitas et al. 2004). Soil pH was around of this value. Organic matter $(\mathrm{OM})$ concentration of soils ranged between 0.77 and 2.69 , with a mean of $1.8 \%$. Total nitrogen showed percentage below $0.091 \%$, resulting in high $\mathrm{C} / \mathrm{N}$ ratios $(17.17$ - 45.04), this could suggest poor humification of organic matter, which might be due to low or disturbed soil microbial activity (Remon et al. 2005). Furthermore, in this soil samples the $\mathrm{pH}$, conductivity, $\mathrm{OM}$ and TKN were the lowest, as well as found by Ma and Dong (2004), Remon et al. (2005), Barrutia et al. (2011). It is known that polluted mining soils are characterized by low nutrient content and adverse conditions for plant growing (Wong 2003; Freitas et al. 2004). Under these conditions, the competition for main nutrients such as nitrogen or phosphorus represents a limiting factor for plants and soil microorganisms (Unterbrunner et al. 2007).

Soil metal concentrations were highly heterogeneous among sites, probably due to the nature of mining operations (mineral extraction, storage, mechanical dispersion, presence of overburden 
materials, degree of mineral weathering, etc.) (Barrutia et al. 2011). The concentration of different metals in soil around all selected plant species are shown in Table 2.

Iron showed the highest concentrations in soil $\left(\right.$ mean value $\left.=278557.50 \mathrm{mg} \mathrm{kg}^{-1}\right)$, followed by $\mathrm{P}$ (mean value $=5372.50 \mathrm{mg} \mathrm{kg}^{-1}$ ), but $\mathrm{Cr}$ and $\mathrm{Zn}$ were also detected at relatively high levels $\left(130.39 \mathrm{mg} \mathrm{kg}^{-1}\right.$ and $104.25 \mathrm{mg} \mathrm{kg}^{-1}$, respectively, for mean values). Concentrations of other associated non-target metals, such as $\mathrm{Cd}$ (mean value $\left.=1.47 \mathrm{mg} \mathrm{kg}^{-1}\right), \mathrm{Cu}$ (mean value $=44.90 \mathrm{mg} \mathrm{kg}^{-1}$ ), and $\mathrm{Pb}$ (mean value $=7.24$ $\mathrm{mg} \mathrm{kg}^{-1}$ ), were lower. These metal concentrations are lower than Maximum Allowable Concentrations of metals in agricultural soils proposed by the European common (1986). The Maximum total concentrations of $\mathrm{Cr}, \mathrm{Cu}$ and $\mathrm{Pb}$ were found in the T.4.1 soil (up to 156,62 and $14 \mathrm{mg} \mathrm{kg}^{-1}$, respectively) and of $\mathrm{Cd}, \mathrm{Zn}$, Fe and P in T.3.1 soil (up or equal to 3, 145, 373790 and $8240 \mathrm{mg} \mathrm{kg}^{-1}$, respectively).
Bioavailability of metals to plants and biota including fauna and microorganisms is controlled by their total concentration in the soil and their chemical forms (Freitas et al. 2004). Metal bioavailability is estimated using the $0.01 \mathrm{M} \mathrm{CaCl}_{2}$ extractions (Table 2) a relatively high percentage of the $\mathrm{CaCl}_{2}$ extracted metal content in soil samples especially for $\mathrm{Cd}$ (25.69\% in T.4.1), $\mathrm{Pb}(9.77 \%$ in T.2.1), $\mathrm{Cu}$ (1.48 \% in T.1.1) and $\mathrm{Zn}(1.07 \%$ in T.2.1).

On the other hand, this percentage is low for $\mathrm{P}$ and very low for $\mathrm{Fe}$, while $\mathrm{Cr}$ was almost insoluble $(<0.002 \%)$, as well as found by Remon et al. (2005). Venditti et al. (2000) also showed that heavy metals were poorly soluble in water when $\mathrm{pH}$ was kept between 6.6 and 7.6. Nonetheless, demonstration of Remon et al. (2005) heavy metals are neither leachable nor phytoavailable does not mean that pollutants are immobilized and pose no hazard for the environment and human health.

Table 2 Some physicochemical properties of the Ait Amar iron mining area

\begin{tabular}{|c|c|c|c|c|c|}
\hline Samples & T.1.1 & T.2.1 & T.3.1 & T.4.1 & Average \\
\hline pH (KCl) & $6.13 \pm 0.06$ & $5.60 \pm 0.05$ & $5,44 \pm 0,01$ & $5.06 \pm 0.06$ & 5.56 \\
\hline pH (water) & $7.20 \pm 0.10$ & $6.94 \pm 0.14$ & $7.11 \pm 0.06$ & $6.84 \pm 0.09$ & 7.02 \\
\hline Conductivity & $151.77 \pm 6.2$ & $75.57 \pm 4.40$ & $55.37 \pm 2.30$ & $70.10 \pm 2.00$ & 88.20 \\
\hline OM Content (\%) & 2.69 & 2.68 & 1.07 & 0.77 & 1.80 \\
\hline Water content (\%) & 2.11 & 1.51 & 1.75 & 2.18 & 1.89 \\
\hline TOC (\%) & 1.5593 & 1.5565 & 0.6216 & 0.4447 & 1.0455 \\
\hline NTK (\%) & $0.0908 \pm 0.0003$ & $0.0489 \pm 0.0000$ & $0.0138 \pm 0.0002$ & $0.0140 \pm 0.0000$ & 0.0418 \\
\hline C/N Ratio & 17.17 & 31.83 & 45.04 & 31.76 & 31.45 \\
\hline \multicolumn{6}{|c|}{ Total metal concentration $\left(\mathrm{mg} \mathrm{kg}^{-1}\right)$} \\
\hline $\mathbf{C d}$ & 1.37 & 0.91 & 3.06 & 0.55 & 1.47 \\
\hline $\mathbf{C r}$ & 108.38 & 119.74 & 136.97 & 156.50 & 130.39 \\
\hline $\mathbf{C u}$ & 28.78 & 36.19 & 51.97 & 62.67 & 44.90 \\
\hline $\mathbf{Z n}$ & 76.24 & 65.56 & 145.32 & 129.90 & 104.25 \\
\hline $\mathbf{P b}$ & 12.46 & 0.91 & 0.82 & 14.76 & 7.24 \\
\hline $\mathbf{F e}$ & 228030.00 & 199330.00 & 373790.00 & 313080.00 & 278557.50 \\
\hline $\mathbf{P}$ & 5530.00 & 1540.00 & 8240.00 & 6180.00 & 5372.50 \\
\hline \multicolumn{6}{|c|}{$\mathrm{CaCl}_{2}$ extractable metal concentration $\left(\mathrm{mg} \mathrm{kg}^{-1}\right)$} \\
\hline Cd & 0.14 & 0.14 & 0.13 & 0.14 & 0.1375 \\
\hline $\mathrm{Cr}$ & - & - & - & - & - \\
\hline $\mathbf{C u}$ & 0.43 & 0.23 & 0.41 & 0.26 & 0.3325 \\
\hline $\mathbf{Z n}$ & 0.38 & 0.70 & 0.37 & 0.49 & 0.485 \\
\hline $\mathbf{P b}$ & - & 0.09 & - & - & 0.09 \\
\hline $\mathbf{F e}$ & 0.20 & 0.08 & 0.03 & 0.03 & 0.085 \\
\hline $\mathbf{P}$ & 0.78 & 0.12 & 0.60 & 0.09 & 0.3975 \\
\hline
\end{tabular}

-, below detection limit ( $\mathrm{Pb}: 0.004 \mathrm{mg} \mathrm{L}^{-1}, \mathrm{Cr}$ and $\mathrm{Cu}: 0.002 \mathrm{mg} \mathrm{L}^{-1}$ )

Actually, the possibility of horizontal spreading of metal-rich particles due to mechanical erosion and human activities remains. In the case, when the remediation is technically and economically unrealistic, erosion control could be efficiently achieved by phytostabilization (Wong, 2003), i.e. establishing an overall and self-sustainable vegetation cover.

\subsection{Plant accumulation and transport of metals}

Plants that were more popular at the mine were collected and identified for their scientific name and family name. Analyses of metals in the shoots and roots of plants are summarized in Table 3 and show that shoot contents vary between 0.827 and $0.989 \mathrm{mg}$
$\mathrm{Cd} \mathrm{kg}^{-1}, 0.67$ and $9.241 \mathrm{mg} \mathrm{Cr} \mathrm{kg}^{-1}, 12.421$ and 29.19 $\mathrm{mg} \mathrm{Cu} \mathrm{kg}{ }^{-1}, 204.816$ and $1522.839 \mathrm{mg} \mathrm{Fe} \mathrm{kg}^{-1}, 0.366$ and $5.952 \mathrm{mg} \mathrm{Pb} \mathrm{kg}^{-1}, 33.521$ and $175.347 \mathrm{mg} \mathrm{Zn} \mathrm{kg}^{-1}$ and 1405.066 and $4612.795 \mathrm{mg} \mathrm{P} \mathrm{kg}^{-1}$. Cadmium concentrations in shoots and roots are in the same range for the twelve plant species studied $(\sim 0.93 \mathrm{mg}$ $\mathrm{kg}^{-1}$ ).

Normal and toxic concentrations of heavy metals $\left(\mathrm{mg} \mathrm{kg}^{-1}\right)$ are respectively considered to be $0.1-0.5$ and 5-30 for $\mathrm{Cr}, 5-30$ and 20-100 for $\mathrm{Cu}, 27-150$ and $100-400$ for $\mathrm{Zn}, 0.05-0.2$ and 5-30 for $\mathrm{Cd}$, and 5-10 and 30-300 for $\mathrm{Pb}$ (Kabata-Pendias and Pendias, 1992). All of the collected plant species show the concentrations higher than these normal levels for $\mathrm{Cd}$ and $\mathrm{Cr}$. 
By comparing the values obtained with the critical concentrations above which toxicity effects are possible, we have found that the levels critical in this range are: $\mathrm{Cr}$ for $C$. arabicus (L) Cass, $\mathrm{Cu}$ for $E$. ilicifolium Lam. C. lanatus L. E. spinosus $L$. and $\mathrm{Zn}$ for $E$. spinosus $L$. For $\mathrm{Zn}$, it is shown that the concentration of $100 \mathrm{mg} \mathrm{kg}^{-1}$ in feed is considered to be chronically toxic for animals (Dudka et al. 1995). In relation to $\mathrm{Pb}$, L. hispidilus (delile) boiss shows higher concentrations, more of the normal range. And this shows that these plants had a strong ability to tolerate heavy metals.
Yoon et al. (2006) reported concentrations (mg $\mathrm{kg}^{-1}$ ) varying from undetectable to $1183,6-460$ and 17-598 for $\mathrm{Pb}, \mathrm{Cu}$ and $\mathrm{Zn}$, respectively, in native plants growing on a contaminated site. MorenoJimenez et al. (2009) reported concentrations ( $\mathrm{mg} \mathrm{kg}^{-}$ $\left.{ }^{1}\right)$ varying of $\mathrm{Cu}, \mathrm{Zn}$, and $\mathrm{Cd}$ of 2.68-70.2, 9.5-1048, and undetectable to 22.04 , respectively, in shoots of plants growing in an area surrounding a mine site. Stoltz and Greger (2002) reported concentrations of $\mathrm{Cu}, \mathrm{Zn}, \mathrm{Cd}$, and $\mathrm{Pb}$ of $6.4-160,68-1630,0.1-12.5$, and $3.4-920 \mathrm{mg} \mathrm{kg}^{-1}$, respectively in wetland plant species growing on submerged mine tailings.

Table 3 Concentrations ( $\mathrm{mg} \mathrm{kg}^{-1}$ dry weight (DW) material) of $\mathrm{Cd}, \mathrm{Cr}, \mathrm{Cu}, \mathrm{Fe}, \mathrm{Pb}, \mathrm{Zn}$ and $\mathrm{P}$ in the shoot and root tissues of different study species

\begin{tabular}{|c|c|c|c|c|c|c|c|c|c|}
\hline Family & Species & Organs & Cd & $\mathbf{C r}$ & $\mathbf{C u}$ & $\mathbf{F e}$ & $\mathbf{P b}$ & $\mathbf{Z n}$ & $\mathbf{P}$ \\
\hline \multirow{4}{*}{ Apiaceae } & \multirow{2}{*}{ Eryngium ilicifolium Lam. } & Root & 0.675 & 1.455 & 6.806 & 1134.062 & 0.104 & 67.177 & 5.351 \\
\hline & & Shoot & $0.830^{a}$ & $1.090^{b}$ & $25.484 *^{c}$ & 565.225 & 0.727 & 63.789 & 2877.509 \\
\hline & \multirow{2}{*}{$\frac{\text { Eryngium triquetrum }}{\text { Vahl. }}$} & Root & 0.937 & 1.874 & 27.854 & 721.641 & - & 54.458 & 823.527 \\
\hline & & Shoot & $0.837^{a}$ & $1.516^{b}$ & 18.771 & 336.144 & 0.366 & 61.592 & 1788.012 \\
\hline \multirow{12}{*}{ Asteraceae } & \multirow{2}{*}{$\begin{array}{c}\frac{\text { Carlina acaulia subsp }}{\text { caulescens }} \\
\end{array}$} & Root & 1.095 & 6.256 & 37.694 & 3002.823 & 43.481 & 64.856 & 1084.044 \\
\hline & & Shoot & $0.927^{a}$ & $0.670^{b}$ & 18.704 & 204.816 & - & 71.724 & 1470.299 \\
\hline & \multirow[b]{2}{*}{ Carthamus lanatus $L}$. & Root & 1.182 & 2.456 & 2.456 & 2159.485 & 0.273 & 101.962 & 17.191 \\
\hline & & Shoot & $0.888^{a}$ & $0.940^{b}$ & $20.628^{* c}$ & 892.077 & 1.044 & 72.956 & 1405.066 \\
\hline & \multirow{2}{*}{$\frac{\text { Cladanthus arabicus }(\text { L.) }}{\text { Cass. }}$} & Root & 0.889 & 4.601 & 29.960 & 2516.769 & 8.366 & 70.272 & 1584.098 \\
\hline & & Shoot & $0.878^{a}$ & $9.241^{* b}$ & 17.244 & 636.567 & 2.478 & 90.400 & 3728.383 \\
\hline & \multirow[b]{2}{*}{ Echinops spinosus $L}$. & Root & 1.152 & 5.341 & 45.657 & 2746.996 & 10.681 & 69.480 & 845.801 \\
\hline & & Shoot & $0.989^{a}$ & $0.728^{b}$ & $29.190^{* c}$ & 297.778 & - & $175.347 *^{e}$ & 2622.346 \\
\hline & \multirow{2}{*}{$\frac{\text { Leontodon hispidilus }}{\underline{\text { Delile }) \text { Boiss. }}}$} & Root & 0.993 & 4.755 & 29.625 & 2877.625 & 13.115 & 135.796 & 2551.120 \\
\hline & & Shoot & $0.835^{a}$ & $2.506^{b}$ & 19.005 & 1522.839 & $5.952^{d}$ & 85.525 & 4612.795 \\
\hline & \multirow{2}{*}{ Scolymus hispanicus $L}$. & Root & 0.918 & 5.048 & 28.708 & 3113.491 & 17.286 & 79.189 & 2123.558 \\
\hline & & Shoot & $0.827^{a}$ & $2.531^{b}$ & 15.601 & 346.005 & 1.085 & 58.322 & 3058.514 \\
\hline \multirow{8}{*}{ Poaceae } & \multirow{2}{*}{ Bromus hordeaceus } & Root & 0.990 & 7.157 & 5.939 & 4391.650 & 47.817 & 123.350 & 31.218 \\
\hline & & Shoot & $0.830^{a}$ & $4.514^{b}$ & 14.631 & 417.136 & 1.920 & 39.379 & 2074.059 \\
\hline & \multirow{2}{*}{ Bromus rubens $L}$. & Root & 1.271 & 10.064 & 36.799 & 3036.247 & 30.802 & 118.937 & 2451.017 \\
\hline & & Shoot & $0.866^{a}$ & $4.583^{b}$ & 15.989 & 357.570 & 1.629 & 58.661 & 2251.899 \\
\hline & \multirow{2}{*}{$\frac{\text { Lamarckia aurea L. }}{\text { (Moench). }}$} & Root & 1.206 & 7.917 & 31.983 & 3003.610 & 55.945 & 215.338 & 1732.296 \\
\hline & & Shoot & $0.839^{a}$ & $4.037^{b}$ & 17.145 & 930.875 & 1.573 & 66.851 & 1697.638 \\
\hline & \multirow{2}{*}{ Stipa capensis Thunb. } & Root & 0.668 & 11.659 & 8.320 & 2928.177 & 104.825 & 77.245 & 26.707 \\
\hline & & Shoot & $0.832^{a}$ & $3.950^{b}$ & 12.421 & 371.065 & - & 33.521 & 1596.464 \\
\hline
\end{tabular}

, Below detection limit ( $\mathrm{Pb}: 0.004 \mathrm{mg} / \mathrm{L})$.

*, The values in the range of critical concentrations for plants (Kabata-Pendias and Pendias, 1992)

$a, b, c, d, e$, The values are higher of the normal range of $\mathrm{Cd}, \mathrm{Cr}, \mathrm{Cu}, \mathrm{Pb}$ and $\mathrm{Zn}$ in plant respectively (Kabata-Pendias and Pendias, 1992 ).

Rio et al. (2002) reported concentrations (mg kg${ }^{1}$ ) of $\mathrm{Pb}, \mathrm{Zn}, \mathrm{Cu}$ and $\mathrm{Cd}$ varying from of undetectable to $450,13-1138,1.2-152$ and from undetectable to 9.7 , respectively, in wild vegetation in a river area after a toxic spill at a mine site. In an analysis of wetland plant species collected from mine tailings, Deng et al. (2008) reported concentrations of up to 11116, 1249, and $1090 \mathrm{mg} \mathrm{kg}^{-1}$ for $\mathrm{Zn}, \mathrm{Pb}$, and $\mathrm{Cd}$, respectively, in Sedum alfredii growing on tailings at a $\mathrm{Pb}-\mathrm{Zn}$ mine. Chehregani et al. (2009) reported concentrations $\left(\mathrm{mg} \mathrm{kg}^{-1}\right)$ varying from of undetectable to $14.6,9.60-84.0,4.00-1485$, and $20.0-1987$ for $\mathrm{Cd}$, $\mathrm{Cu}, \mathrm{Pb}$, and $\mathrm{Zn}$, respectively, in shoots and leaves of plants collected in a waste pool at a $\mathrm{Pb}-\mathrm{Zn}$ mine.

In the present study, the concentrations of $\mathrm{Pb}$, $\mathrm{Cu}, \mathrm{Zn}$ and $\mathrm{Cd}$ are in agreement with those of previous studies reported by Yoon et al. (2006), Moreno-Jimenez et al. (2009), Stoltz and Greger (2002), Rio et al. (2002) and Chehregani et al. (2009). But lower than the concentrations of $\mathrm{Zn}, \mathrm{Pb}$ and $\mathrm{Cd}$ in the plants assessed by Deng et al. (2008), and higher than the concentrations of $\mathrm{Zn}, \mathrm{Cu}, \mathrm{Pb}$ and $\mathrm{Cr}$ determined by Remon et al. (2005). The concentrations of $\mathrm{Fe}$ conform to the concentrations reported by Lorestani et al. (2011) $\left(\mathrm{mg} \mathrm{kg}^{-1}\right) 349.6-$ 22645.3 in roots and 309.6-10604.9 in shoots.

Metals accumulation by the site's vegetation was checked by measuring metal concentrations in shoots and roots from the dominant species taken (Table ). In shoots, the average metal contents were $0.86 \mathrm{mg}$ $\mathrm{kg}^{-1}$ for $\mathrm{Cd}, 3.02 \mathrm{mg} \mathrm{kg}^{-1}$ for $\mathrm{Cr}, 18.73 \mathrm{mg} \mathrm{kg}^{-1}$ for $\mathrm{Cu}$, $573.17 \mathrm{mg} \mathrm{kg}^{-1}$ for $\mathrm{Fe}, 1.86 \mathrm{mg} \mathrm{kg}^{-1}$ for $\mathrm{Pb}, 73.13 \mathrm{mg}$ $\mathrm{kg}^{-1}$ for $\mathrm{Zn}$ and $2431.91 \mathrm{mg} \mathrm{kg}-1$ for P. As a general trend, root metal concentrations were slightly higher for all metals, with a mean of $0.99 \mathrm{mg} \mathrm{kg}-1$ for $\mathrm{Cd}$, $5.71 \mathrm{mg} \mathrm{kg}-1$ for $\mathrm{Cr}, 24.31 \mathrm{mg} \mathrm{kg}-1$ for $\mathrm{Cu}, 2636.05$ mg kg-1 for Fe, $30.24 \mathrm{mg} \mathrm{kg}-1$ for $\mathrm{Pb}$ and $98.17 \mathrm{mg}$ $\mathrm{kg}-1$ for $\mathrm{Zn}$, except $\mathrm{P}$ with $1106.33 \mathrm{mg} \mathrm{kg}-1$ as a mean. Remon et al. (2005) also noticed the same trend for $\mathrm{Zn}, \mathrm{Cu}, \mathrm{Pb}$ and $\mathrm{Cr}$. Metal excluders accumulate metals from substrate into their roots but restrict their transport and entry into their aerial parts (Malik and Biswas, 2012). Such plants have a low potential for metal extraction but may be efficient for 
phytostabilization purposes (Lasat, 2002). Although the reason for such a higher $\mathrm{P}$ content in shoots than in roots, that could be due to the distribution and dynamics of $\mathrm{P}$ in soil, rhizosphere and plant processes associated with soil $\mathrm{P}$ transformation, $\mathrm{P}$ mobilization and $\mathrm{P}$ acquisition, also could suggest root morphology, root architecture and root physiology, $\mathrm{Pi}$ transporters localized in the plasma membranes of roots, mycorrhizal and microbial activity (Schachtman et al. 1998; Raghothama and Karthikeyan 2005; Shen et al. 2011). The decreasing uptake of $\mathrm{Cd}$ by roots supplied with increasing $\mathrm{Zn}$ concentration found in $\mathrm{Cd} / \mathrm{Zn}$ hyperaccumulator $\mathrm{A}$. halleri and in most ecotypes of T. caerulescens clearly demonstrates that $\mathrm{Cd}$ influx is largely due to $\mathrm{Zn}$ transporters, with a strong preference for $\mathrm{Zn}$ over $\mathrm{Cd}$ (Zhao et al. 2002).

Accumulation of metals in organ plants arranged in the order, for roots: $\mathrm{Fe}, \mathrm{P}, \mathrm{Zn}, \mathrm{Pb}, \mathrm{Cu}, \mathrm{Cr}, \mathrm{Cd}$ and for shoots: $\mathrm{P}, \mathrm{Fe}, \mathrm{Zn}, \mathrm{Cu}, \mathrm{Cr}, \mathrm{Pb}, \mathrm{Cd}$. Kisku et al. (2011) found plants (e.g. Wheat, Anise, Datura) absorbed larger proportion of $\mathrm{Zn}$ than $\mathrm{Cu}$ and $\mathrm{Pb}$. E. ilicifolium Lam, E. triquetrum Vahl. C. lanatus L. C. arabicus (L.) Cass. E. spinosus L. L. hispidilus (Delile) Bois, S. hispanicus L. B. rubens L. and contained higher quantities of $\mathrm{Fe}, \mathrm{Zn}$ and $\mathrm{Cu}$, which are micronutrients in plants, compared to $\mathrm{Pb}$ and $\mathrm{Cd}$, the elements toxic (Lasat 2000).

However, differences between the metal content of roots and shoots were significant (Pearson correlation test, $\mathrm{p}<0.05$ regardless of the metal) unless for E. triquetrum Vahl, L. hispidilus (Delile) Boiss and L. aurea L. (Moench) (Table 5). This indicates that, in this plant community, metal concentrations were not in high equilibrium between roots and shoots. Consequently, each metal was accumulated with a good content in roots $(\mathrm{Cd}, \mathrm{Cr}, \mathrm{Cu}, \mathrm{Pb}, \mathrm{Zn}$ and $\mathrm{Fe}$ ) or in shoots $(\mathrm{P})$. Metals $(\mathrm{Cd}, \mathrm{Cr}, \mathrm{Cu}, \mathrm{Pb}, \mathrm{Zn}$ and $\mathrm{Fe})$ and $\mathrm{P}$ concentrations extracted with a $0.01 \mathrm{M}$ $\mathrm{CaCl}_{2}$ solution, which represent the soluble and easily exchangeable metal fraction in the soil (Houba et al. 1996; Pueyo et al. 2004; Walker et al. 2003; Pérez-deMora et al. 2006), were not correlated with their contents in the plants (Table 4). This fact is confirming that metals and $\mathrm{P}$ concentrations in the plants could not be considered as a good "indicator" of metals and P availability in the soil (Baker, 1981). Similar results were obtained by Alvarenga et al. 2009, for $\mathrm{Cu}, \mathrm{Pb}$ and $\mathrm{Zn}$ using Lolium perenne $L$.

However, our results also suggest that, independently of the soil metal content, the different plant species present on the site had the same abilities to take up and accumulate metals (Kruskal-Wallis test $\mathrm{p}<0.05$, using shoots and roots data $(r=1$ and 0.86 respectively)). Our statistic results e differ from those of Remon et al. (2005) for $\mathrm{Cu}, \mathrm{Cr}, \mathrm{Pb}$ and $\mathrm{Zn}$, reported that the different plant species present on the site had varying abilities to take up and accumulate metals. This may be due, first to the contamination origin of soil (natural or anthropogenic), second to the vegetable species used.

None of the plants studied exceed the contents proposed by Baker and Brooks (1989) to be accepted as hyperaccumulators. Furthermore, on only one occasion the BCF reaches a value higher than 1 and this is with $\mathrm{Zn}$ in E. spinosus L. (Table 6).

Table 4 Correlation between available metals and their contents in the plants

\begin{tabular}{|c|c|c|c|c|c|c|c|c|c|c|c|c|}
\hline & $\begin{array}{l}\text { Available } \\
\text { Cd }\end{array}$ & $\begin{array}{l}\text { Available } \\
\mathrm{Cu}\end{array}$ & $\begin{array}{c}\text { Available } \\
\text { Fe }\end{array}$ & $\begin{array}{c}\text { Available } \\
\text { Zn }\end{array}$ & Available P & Plant Cd & Plant $\mathrm{Cr}$ & $\begin{array}{c}\text { Plant } \\
\mathrm{Cu}\end{array}$ & $\begin{array}{l}\text { Plant } \\
\text { Fe }\end{array}$ & \begin{tabular}{|c|} 
Plant \\
$\mathrm{Pb}$
\end{tabular} & $\begin{array}{l}\text { Plant } \\
\text { Zn }\end{array}$ & $\begin{array}{l}\text { Plant } \\
\text { P }\end{array}$ \\
\hline $\begin{array}{l}\text { Available } \\
\text { Cd }\end{array}$ & 1 & & & & & & & & & & & \\
\hline $\begin{array}{c}\text { Available } \\
\mathrm{Cu}\end{array}$ & $-0,519$ & 1 & & & & & & & & & & \\
\hline $\begin{array}{c}\text { Available } \\
\text { Fe }\end{array}$ & 0,369 & 0,454 & 1 & & & & & & & & & \\
\hline $\begin{array}{c}\text { Available } \\
\text { Zn }\end{array}$ & 0,419 & $-0,895$ & $-0,204$ & 1 & & & & & & & & \\
\hline $\begin{array}{c}\text { Available } \\
\text { P }\end{array}$ & $-0,425$ & $0,975^{*}$ & 0,619 & $-0,789$ & 1 & & & & & & & \\
\hline Plant Cd & $-0,340$ & $-0,340$ & $-0,972 *$ & 0,018 & $-0,534$ & 1 & & & & & & \\
\hline Plant $\mathrm{Cr}$ & -0,954* & 0,331 & $-0,622$ & $-0,349$ & 0,189 & $-0,015$ & 1 & & & & & \\
\hline Plant $\mathrm{Cu}$ & $-0,854$ & 0,234 & $-0,252$ & 0,040 & 0,239 & 0,563 & $-0,103$ & 1 & & & & \\
\hline Plant Fe & $-0,455$ & 0,282 & $-0,610$ & $-0,626$ & 0,061 & 0,265 & 0,545 & $-0,101$ & 1 & & & \\
\hline Plant $\mathrm{Pb}$ & $-0,980^{*}$ & 0,517 & $-0,461$ & $-0,506$ & 0,386 & $-0,197$ & $0,716^{* *}$ & $-0,314$ & 0,458 & 1 & & \\
\hline Plant Zn & 0,258 & $-0,144$ & $-0,437$ & $-0,309$ & $-0,315$ & $0,632^{*}$ & 0,094 & 0,475 & 0,469 & $-0,042$ & 1 & \\
\hline Plant $\mathrm{P}$ & $-0,347$ & 0,533 & 0,640 & $-0,101$ & 0,681 & 0,063 & 0,150 & 0,473 & 0,289 & $-0,288$ & 0,326 & 1 \\
\hline
\end{tabular}

**. Correlation is significant at the 0.01 level.

*. Correlation is significant at the 0.05 level. 


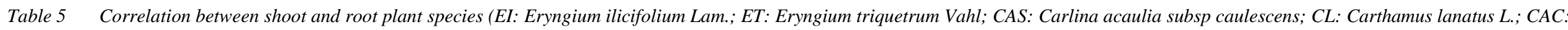
Cladanthus arabicus (L.) Cass; ES: Echinops spinosus L.; LH: Leontodon hispidilus (Delile) Boiss; SH: Scolymus hispanicus L.; BH: Bromus hordeaceus; BR: Bromus rubens L.; LA:

Lamarckia aurea L. (Moench). and SC: Stipa capensis Thunb.)

\begin{tabular}{|c|c|c|c|c|c|c|c|c|c|c|c|c|c|c|c|c|c|c|c|c|c|c|c|c|}
\hline & $\begin{array}{c}\text { Root } \\
\text { EI }\end{array}$ & $\begin{array}{c}\text { Shoot } \\
\text { EI }\end{array}$ & $\begin{array}{l}\text { Root } \\
\text { ET }\end{array}$ & $\begin{array}{c}\text { Shoot } \\
\text { ET }\end{array}$ & $\begin{array}{l}\text { Root } \\
\text { CAS }\end{array}$ & $\begin{array}{l}\text { Shoot } \\
\text { CAS }\end{array}$ & $\begin{array}{l}\text { Root } \\
\text { CL }\end{array}$ & $\begin{array}{l}\text { Shoot } \\
\text { CL }\end{array}$ & $\begin{array}{l}\text { Root } \\
\text { CAC }\end{array}$ & $\begin{array}{l}\text { Shoot } \\
\text { CAC }\end{array}$ & $\begin{array}{c}\text { Root } \\
\text { ES }\end{array}$ & $\begin{array}{c}\text { Shoot } \\
\text { ES }\end{array}$ & $\begin{array}{l}\text { Root } \\
\text { LH }\end{array}$ & $\begin{array}{c}\text { Shoot } \\
\text { LH }\end{array}$ & $\begin{array}{c}\text { Root } \\
\text { SH }\end{array}$ & $\begin{array}{c}\text { Shoot } \\
\text { SH }\end{array}$ & $\begin{array}{c}\text { Root } \\
\text { BH }\end{array}$ & $\begin{array}{c}\text { Shoot } \\
\text { BH }\end{array}$ & $\begin{array}{c}\text { Root } \\
\text { BR }\end{array}$ & $\begin{array}{c}\text { Shoot } \\
\text { BR }\end{array}$ & $\begin{array}{c}\text { Root } \\
\text { LA }\end{array}$ & $\begin{array}{c}\text { Shoot } \\
\text { LA }\end{array}$ & $\begin{array}{c}\text { Root } \\
\text { SC }\end{array}$ & Shoot SC \\
\hline Root EI & 1 & & & & & & & & & & & & & & & & & & & & & & & \\
\hline Shoot EI & 0,017 & 1 & & & & & & & & & & & & & & & & & & & & & & \\
\hline Root ET & 0,557 & $0,818^{*}$ & 1 & & & & & & & & & & & & & & & & & & & & & \\
\hline Shoot ET & 0,007 & $1,00^{* *}$ & $0,812^{*}$ & 1 & & & & & & & & & & & & & & & & & & & & \\
\hline Root CAS & $0,934^{* *}$ & 0,372 & $0,819^{*}$ & 0,361 & 1 & & & & & & & & & & & & & & & & & & & \\
\hline Shoot CAS & $\begin{array}{ll}-0,085 \\
\end{array}$ & $0,998^{* * *}$ & 0,779 & $0,998^{* * *}$ & 0,279 & 1 & & & & & & & & & & & & & & & & & & \\
\hline Root CL & $1,00^{* *}$ & 0,024 & 0,563 & 0,013 & $0,936^{* *}$ & $-0,078$ & 1 & & & & & & & & & & & & & & & & & \\
\hline Shoot CL & 0,419 & $0,915^{* *}$ & $0,982^{* *}$ & $0,911^{* *}$ & 0,714 & $0,883^{*}$ & 0,424 & 1 & & & & & & & & & & & & & & & & \\
\hline Root CAC & $0,818^{*}$ & 0,588 & $0,936^{* *}$ & 0,579 & $0,969^{* *}$ & 0,51 & $0,822^{*}$ & \begin{tabular}{|l|}
$0,864^{*}$ \\
\end{tabular} & 1 & & & & & & & & & & & & & & & \\
\hline Shoot CAC & \begin{tabular}{|c|}
$-0,009$ \\
\end{tabular} & $1,00^{* *}$ & 0,803 & $1,00^{* * *}$ & 0,347 & $0,999^{* * *}$ & $-0,002$ & $0,904^{* * *}$ & 0,567 & 1 & & & & & & & & & & & & & & \\
\hline Root ES & $0,951^{* *}$ & 0,322 & 0,786 & 0,312 & $0,999^{* *}$ & 0,226 & $0,953^{* *}$ & 0,676 & $0,955^{* *}$ & 0,297 & 1 & & & & & & & & & & & & & \\
\hline Shoot ES & $-0,114$ & $0,994^{* * *}$ & 0,76 & $0,996^{* *}$ & 0,25 & $0,999^{* * * *}$ & $-0,107$ & $0,869^{*}$ & 0,484 & $0,997^{* *}$ & 0,197 & 1 & & & & & & & & & & & & \\
\hline Root LH & 0,693 & 0,733 & $0,987^{* *}$ & 0,725 & $0,904^{* *}$ & 0,672 & 0,698 & $0,945^{* *}$ & $0,981^{* *}$ & 0,715 & $0,880^{* *}$ & 0,649 & 1 & & & & & & & & & & & \\
\hline Shoot LH & 0,152 & $0,991^{* * *}$ & $0,889^{*}$ & $0,989^{* *}$ & 0,494 & $0,979^{* * * *}$ & 0,159 & $0,961^{* *}$ & 0,692 & $0,987^{* *}$ & 0,448 & $0,972^{* * *}$ & $0,818^{*}$ & 1 & & & & & & & & & & \\
\hline Root SH & $0,792^{*}$ & 0,623 & $0,951^{* *}$ & 0,614 & $0,958^{* *}$ & 0,549 & $0,797^{*}$ & $0,885^{* *}$ & $0,999^{* *}$ & 0,602 & $0,941^{* *}$ & 0,523 & $0,989^{* * *}$ & 0,723 & 1 & & & & & & & & & \\
\hline Shoot SH & $-0,066$ & $0,996^{* *}$ & 0,767 & $0,997^{* *}$ & 0,293 & $0,999^{* *}$ & $-0,06$ & $0,878^{* * *}$ & 0,518 & $0,998^{* *}$ & 0,242 & $0,999^{* *}$ & 0,673 & $0,976^{* *}$ & 0,555 & 1 & & & & & & & & \\
\hline Root BH & $0,999^{* * *}$ & 0,024 & 0,566 & 0,013 & $0,937^{* *}$ & $\begin{array}{l}-0,075 \\
\end{array}$ & $1,00^{* * *}$ & 0,424 & $0,823^{*}$ & $\begin{array}{l}-0,002 \\
\end{array}$ & $0,954^{* *}$ & $-0,105$ & $\begin{array}{ll}0,698 \\
\end{array}$ & 0,159 & $0,797^{*}$ & $-0,06$ & 1 & & & & & & & \\
\hline Shoot BH & 0,022 & $1,00^{* *}$ & $0,821^{*}$ & $1,00^{* *}$ & 0,376 & $0,997^{* * *}$ & 0,029 &, $917^{* *}$ & 0,592 & $0,999^{* *}$ & 0,327 & $0,994^{* * *}$ & 0,736 & $0,991^{* * *}$ & 0,627 & $0,996^{* *}$ & 0,029 & 1 & & & & & & \\
\hline Root BR & 0,731 & 0,694 & $0,977^{* *}$ & 0,686 & $0,926^{* *}$ & 0,628 & 0,736 & $0,925^{* *}$ & $0,990^{* *}$ & 0,675 & $0,905^{* *}$ & 0,604 & $0,998^{* *}$ & $0,785^{*}$ & $0,995^{* *}$ & 0,631 & 0,737 & 0,698 & 1 & & & & & \\
\hline Shoot BR & $-0,022$ & $0,999^{* *}$ & 0,795 & $1,00^{* *}$ & 0,335 & $0,999^{* * *}$ & $-0,015$ & $0,899^{* *}$ & 0,556 & $1,00^{* * *}$ & 0,285 & $0,998^{* *}$ & 0,706 & $0,985^{* *}$ & 0,592 & $0,999^{* *}$ & $-0,015$ & $0,999^{* *}$ & 0,665 & 1 & & & & \\
\hline Root LA & $0,846^{*}$ & 0,547 & $0,918^{* *}$ & 0,538 & $0,979^{* *}$ & 0,467 & $0,850^{*}$ & \begin{tabular}{|l|}
$0,838^{*}$ \\
\end{tabular} & $0,998^{* *}$ & 0,525 & $0,968^{* *}$ & $\begin{array}{ll}0,441 \\
\end{array}$ & $0,970^{* * *}$ & 0,655 & $0,995^{* *}$ & 0,475 & $0,850^{*}$ & 0,551 & $0,982^{* * *}$ & 0,514 & 1 & & & \\
\hline Shoot LA & 0,35 & $0,943^{* * *}$ & $0,965^{* *}$ & $0,939^{* *}$ & 0,66 & $0,916^{*}$ & 0,356 & $0,997^{* *}$ & $0,824^{*}$ & $0,934^{* *}$ & 0,62 & $0,904^{*}$ & $0,918^{* * *}$ & $0,979^{* * *}$ & $0,848^{*}$ & $0,911^{* *}$ & \begin{tabular}{|c|}
0,356 \\
\end{tabular} & $0,944^{* * *}$ & $0,894^{* * *}$ & $0,929^{* * *}$ & 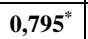 & 1 & & \\
\hline Root SC & $0,999^{* * *}$ & 0,02 & 0,567 & 0,01 & $0,936^{* *}$ & $-0,074$ & $0,999^{* *}$ & 0,421 & $0,820^{*}$ & $-0,006$ & $0,952^{* *}$ & $-0,103$ & 0,695 & 0,156 & $0,795^{*}$ & $-0,063$ & $1,00^{* * *}$ & 0,026 & 0,734 & $-0,019$ & $0,847^{*}$ & 0,353 & 1 & \\
\hline Shoot SC & 0,016 & $0,999^{* *}$ & $0,839^{*}$ & $0,999^{* *}$ & 0,376 & $0,994^{* * *}$ & 0,023 & $0,926^{* * *}$ & 0,596 & $0,998^{* *}$ & 0,324 & $0,990^{* * *}$ & 0,743 & $0,995^{* * *}$ & 0,631 & $0,993^{* *}$ & \begin{tabular}{|c|}
0,027 \\
\end{tabular} & $1,00^{* * *}$ & 0,704 & $0,997^{* *}$ & \begin{tabular}{|l|l|}
0,554 \\
\end{tabular} & $0,952^{* *}$ & 0,028 & 1 \\
\hline
\end{tabular}

**. Correlation is significant at the 0.01 level.

*. Correlation is significant at the 0.05 level 
Bioncentration factors of $\mathrm{Cd}, \mathrm{Cr}, \mathrm{Cu}, \mathrm{Fe}, \mathrm{Pb}, \mathrm{Zn}$ and $\mathrm{P}$ of the different study species

\begin{tabular}{|c|c|c|c|c|c|c|c|c|}
\hline & & \multicolumn{7}{|c|}{$\overline{\text { BCF }}$} \\
\hline Family & Species & Cd & $\mathrm{Cr}$ & $\mathbf{C u}$ & $\mathbf{F e}$ & $\mathbf{P b}$ & Zn & $\overline{\mathbf{P}}$ \\
\hline \multirow{2}{*}{ Apiaceae } & Eryngium ilicifolium Lam. & 0.564 & 0.008 & 0.568 & 0.002 & 0.100 & 0.612 & 0.536 \\
\hline & Eryngium triquetrum Vahl. & 0.569 & 0.012 & 0.418 & 0.001 & 0.051 & 0.591 & 0.333 \\
\hline \multirow{6}{*}{ Asteraceae } & Carlina acaulia subsp caulescens & 0.630 & 0.005 & 0.417 & 0.001 & - & 0.688 & 0.274 \\
\hline & Carthamus lanatus $L$. & 0.603 & 0.007 & 0.459 & 0.003 & 0.144 & 0.700 & 0.262 \\
\hline & Cladanthus arabicus (L.) Cass. & 0.597 & 0.071 & 0.384 & 0.002 & 0.343 & 0.867 & 0.694 \\
\hline & Echinops spinosus L. & 0.672 & 0.006 & 0.650 & 0.001 & - & 1.682 & 0.488 \\
\hline & Leontodon hispidilus (Delile) Boiss. & 0.568 & 0.019 & 0.423 & 0.005 & 0.823 & 0.820 & 0.859 \\
\hline & Scolymus hispanicus $L$. & 0.562 & 0.019 & 0.347 & 0.001 & 0.150 & 0.559 & 0.569 \\
\hline \multirow{4}{*}{ Poaceae } & Bromus hordeaceus & 0.564 & 0.035 & 0.326 & 0.001 & 0.265 & 0.378 & 0.386 \\
\hline & Bromus rubens $L$. & 0.588 & 0.035 & 0.356 & 0.001 & 0.225 & 0.563 & 0.419 \\
\hline & Lamarckia aurea L. (Moench). & 0.570 & 0.031 & 0.382 & 0.003 & 0.217 & 0.641 & 0.316 \\
\hline & Stipa capensis Thunb. & 0.565 & 0.030 & 0.277 & 0.001 & - & 0.322 & 0.297 \\
\hline
\end{tabular}

Plant metal accumulation is often expressed as a BCF. McGrath and Zhao (2003) considered that BCF $<0.2$ as normal for plants growing on polluted materials. The data presented in this study indicate that hyperaccumulation levels were obtained only for Echinops spinosus L. for $\mathrm{Zn}$ (1.68), and this reflected the ability of this plant species to accumulate this metal from the soil and to transport it from the roots to shoots, and all other plant species had a BCF less than one (Table 6).

Cluster analysis according to the BCF revealed that the three plant species (B. Rubens $L, L$. aurea $L$ (Moench), and B. hordeaceus) presented metal accumulation strictly linked together at a low Squared Euclidean distance of 2 and they linked together with E. ilicifolium Lam, S. hispanicus L, E. triquetrum Vahl, C. acaulia subsp caulescens, $C$. lanatus $L$ and $S$. capensis Thunb at Squared Euclidean distance of 4 and with $C$. arabicus (L) Cass and L. hispidilus (Delile) Boiss at Squared Euclidean distance of 16. However, E. spinosus $L$ was distinctly different, having accumulation capacity at a considerably higher Squared Euclidean distance (Figure 1).

Tolerant plants have TF values $<1$ and hyperaccumulators $>>1$ (Conesa and Faz, 2011). In our case, E. ilicifolium Lam had four TF values > 1: 1.23, 3.74, 6.99 and 537.72 for $\mathrm{Cd}, \mathrm{Cu}, \mathrm{Pb}$ and $\mathrm{P}$, respectively, and one close to 1 (0.95) for $\mathrm{Zn}, C$. lanatus L. C. arabicus (L.) Cass and S. capensis Thunb had three TF values $>1$, E. triquetrum Vahl, $C$. acaulia subsp caulescens, $E$. spinosis and $B$. hordeaceus had two TF values $>1$, L. hispidilus (Delile) Boiss and S. hispanicus L. had only one TF value $>1$ and for other plants all TF values are $<1$ (Table 7).

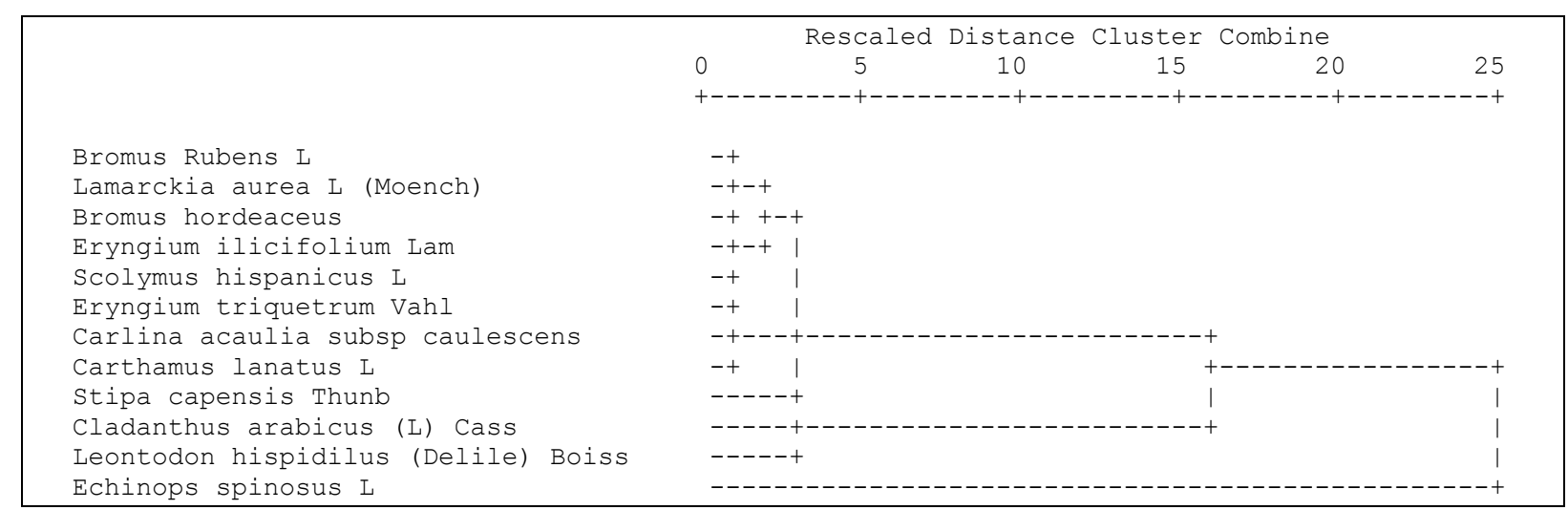

Fig. 1. Hierarchical dendrogram of plants on the basis of BCF obtained by the Ward's hierarchical clustering method

This showed that E. ilicifolium Lam was the most efficient in translocating metals in shoots between these 12 species (Figure 2).

Cluster analysis of plant effectiveness to translocate the metals to the shoots indicated that all vegetable species were closely aligned (at Squared Euclidean distance of 3 ) and dissimilar from $E$. ilicifolium Lam, having a considerably higher ability to translocate the metals from the roots to the shoots
(Figure 3). Better translocation is advantageous to phytoextraction; as it can reduce metal concentrations and thus reduce toxicity potential to the root, and translocation to the shoot is one of the mechanisms of resistance to high metal concentrations (Ghosh and Singh, 2005a, b). The $C$. lanatus $L$ species showed a highest level to translocate metals $(\mathrm{Cu}, \mathrm{TF}=8.400)$. 
Table 7 Metal transfer factors of the different study species

\begin{tabular}{|c|c|c|c|c|c|c|c|c|}
\hline & & \multicolumn{7}{|c|}{ TF } \\
\hline Family & Species & Cd & $\mathbf{C r}$ & $\mathbf{C u}$ & $\mathbf{F e}$ & $\mathbf{P b}$ & $\mathbf{Z n}$ & $\mathbf{P}$ \\
\hline \multirow{2}{*}{ Apiaceae } & Eryngium ilicifolium Lam. & 1.230 & 0.749 & 3.744 & 0.498 & 6.993 & 0.950 & 537.720 \\
\hline & Eryngium triquetrum Vahl. & 0.893 & 0.809 & 0.674 & 0.466 & - & 1.131 & 2.171 \\
\hline \multirow{6}{*}{ Asteraceae } & Carlina acaulia subsp caulescens & 0.847 & 0.107 & 0.496 & 0.068 & - & 1.106 & 1.356 \\
\hline & Carthamus lanatus $L$. & 0.751 & 0.383 & 8.400 & 0.413 & 3.828 & 0.716 & 81.734 \\
\hline & Cladanthus arabicus (L.) Cass. & 0.987 & 2.008 & 0.576 & 0.253 & 0.296 & 1.286 & 2.354 \\
\hline & Echinops spinosus L. & 0.858 & 0.136 & 0.639 & 0.108 & - & 2.524 & 3.100 \\
\hline & Leontodon hispidilus (Delile) Boiss. & 0.842 & 0.527 & 0.642 & 0.529 & 0.454 & 0.630 & 1.808 \\
\hline & Scolymus hispanicus $L$. & 0.901 & 0.501 & 0.543 & 0.111 & 0.063 & 0.736 & 1.440 \\
\hline \multirow{4}{*}{ Poaceae } & Bromus hordeaceus & 0.839 & 0.631 & 2.463 & 0.095 & 0.040 & 0.319 & 66.437 \\
\hline & Bromus rubens $L$. & 0.681 & 0.455 & 0.435 & 0.118 & 0.053 & 0.493 & 0.919 \\
\hline & Lamarckia aurea L. (Moench). & 0.696 & 0.510 & 0.536 & 0.310 & 0.028 & 0.310 & 0.980 \\
\hline & Stipa capensis Thunb. & 1.245 & 0.339 & 1.493 & 0.127 & - & 0.434 & 59.777 \\
\hline
\end{tabular}

Among the 12 plant species collected in the study area, E. spinosus $L$. appears to be the phytoextractor of $\mathrm{Zn}$. This plant accumulated concentration of $\mathrm{Zn}$ as did the other species analyzed in the present study. The other BCFs values of $E$. spinosus L. were $0.67(\mathrm{Cd})$ and $0.65(\mathrm{Cu})$ (Table 6).
But E. ilicifolium Lam appears as a useful species in translocating heavy metals from the roots to shoots. TF values exceeding 1 were obtained for this plant for $\mathrm{Cd}, \mathrm{Cu}, \mathrm{Pb}, \mathrm{P}$, and one value close to 1 was obtained for $\mathrm{Zn}$ (Table 7).
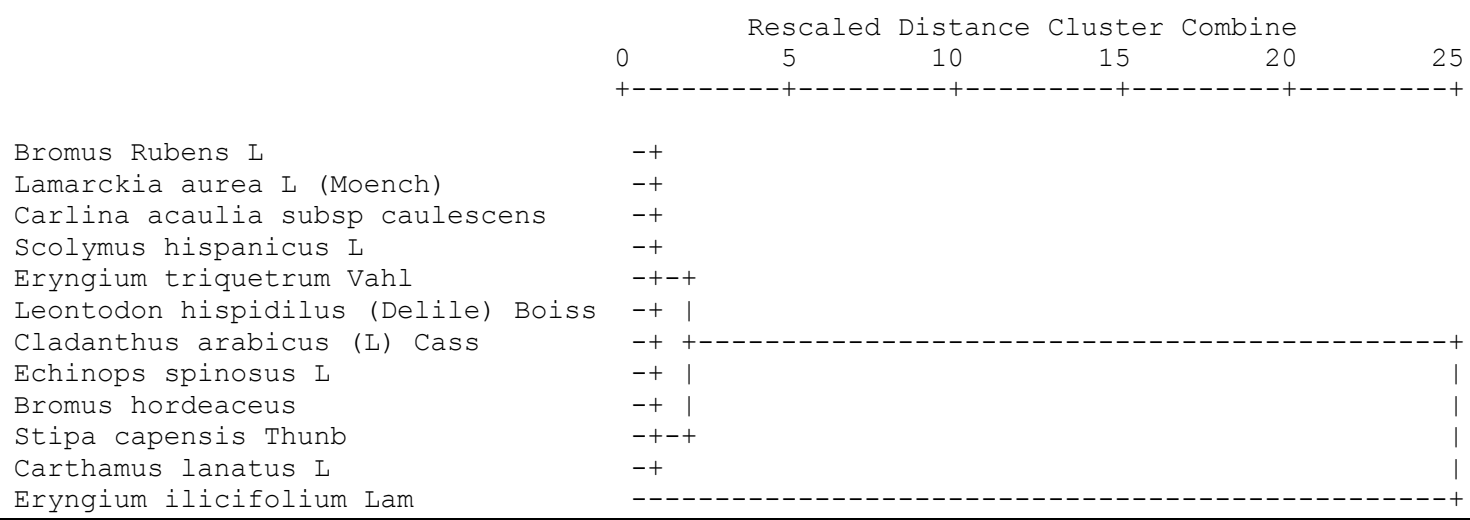

Fig. 2. Groupings of plants on the basis of TF by the Ward's hierarchical clustering method

Finally, phytoextraction process was evaluated according to the metals removal efficiency from soil. Our findings illustrate that $\mathrm{Zn}$ is the highest metals bioavailable, this allowed an enhancement for $E$. spinosus $L$. to accumulate this metal and, consequently, a higher phytoextraction of this metal from contaminated soil. Thus, this can be considered as successful biotechnological tools for the remediation of polluted soils. On the other hand, the plants with $\mathrm{BCF}$ values lower than one indicate that these species can be suitable for phytostabilization.

\section{Conclusions}

Based on the findings of this experimental work, it is identified:

- Metal and phosphorus accumulation depended on the plant species;

- Of the twelve study species, a population was recognized as $\mathrm{Zn}$ phytoextractor (E. spinosus L.), since (i) it accumulated the metal in plant tissues, and (ii) the translocation factor was higher than one;

- Some metallicolous populations concentrated over $1522 \mathrm{mg} \mathrm{Fe} \mathrm{kg}^{-1}$ and over $4612 \mathrm{mg} \mathrm{P} \mathrm{kg}^{-1} \mathrm{DW}$ shoot (L. hispidilus (Delile) Boiss);

- Eleven potential metal excluders represent the candidates for phytostabilization; and

- Some plants can infect the human health through herbivore animals.

For $\mathrm{Zn}$ phytorextraction We propose native accumulator plant, E. spinosus $L$. because of its efficiency to remove $\mathrm{Zn}$. However, there is a need to better understand the precise mechanisms by which $E$. spinosus $L$. extract Zinc from soil. Further work could be performed to validate the impact of metal on growth and metabolism of cereal crops growing around the mine and to study the entry of metals in the food chain. Thus, it has to be pointed out the interest in the potential exploitation of hyperaccumulators (plants or bacteria) as a rich genetic resource to develop engineered phytoextractor plants with high biomass (e.g. eucalyptus) (underway 
results). Furthermore, it is necessary to further investigate other methods for phytoremediation of metal-contaminated soils.

\section{Acknowledgements}

This work was carried out under a Project funded by the North Atlantic Treaty Organization (NATO), within the Program Science for Peace (Ref. SfP.983311). We thank Professor S. HAMMADA (University of Sultan Moulay Slimane, Faculty of Sciences and Techniques) for help in plants identification.

\section{References}

Alexander P. D., Alloway B. J., Dourado A. M., 2006. Genotypic variations in the accumulation of $\mathrm{Cd}, \mathrm{Cu}$, $\mathrm{Pb}$ and $\mathrm{Zn}$ exhibited by six commonly grown vegetables. Environment Pollution, 144, p. 736-745. http://dx.doi.org/10.1016/j.envpol.2006.03.001

Alvarenga P., Gonçalves A.P., Fernandes R.M., De Varennes A., Vallini G., Duarte E., Cunha-Queda A.C. 2009. Organic residues as immobilizing agents in aided phytostabilization: (I) Effects on soil chemical characteristics. Chemosphere 74, p. 1292-1300

http://dx.doi.org/10.1016/j.chemosphere.2008.11.063

Baker A.J.M. 1981. Accumulators and excluders strategies in the response of plants to heavy metals. Journal of Plant Nutrition, 3, p. 643-654.

http://dx.doi.org/10.1080/01904168109362867

Baker A. J. M., Brooks R. R., 1989. Terrestrial higher plants which hyperaccumulate metallic elements-a review of their distribution, ecology and phytochemistry. Biorecovery, 1, p. 81-126.

Barrutia O., Artetxe U., Hernández A., Olano J. M., García-Plazaola J. I., Garbisu C., Becerril J. M., 2011. Native plant communities in an abandoned $\mathrm{Pb}-\mathrm{Zn}$ mining area of northern Spain: Implications for phytoremediation and germplasm preservation. International Journal of Phytoremediation, 13, p. 256-270.

http://dx.doi.org/10.1080/15226511003753946

Chehregani A, Noori M., Yazdi H. L., 2009. Phytoremediation of heavy-metal-polluted soils: Screening for new accumulator plants in Angouran mine (Iran) and evaluation of removal ability. Ecotoxicology and Environmental Safety, 72, p. 1349-1353.

http://dx.doi.org/10.1016/j.ecoenv.2009.02.012

Conesa H. M., Faz Á., 2011. Metal Uptake by Spontaneous Vegetation in Acidic Mine Tailings from a Semiarid Area in South Spain: Implications for Revegetation and Land Management. Water Air Soil Pollution, 215, p. 221-227. http://dx.doi.org/10.1007/s11270-010-0471-4

Deng D. M., Deng J. C., Li J. T., Zhang J., Hu M., Lin Z., Liao B., 2008. Accumulation of zinc, cadmium, and lead in four populations of Sedum alfredii growing on lead/zinc mine spoils. Journal of Integrative Plant Biology, 50 (6), p. 691-698.

http://dx.doi.org/10.1111/j.1744-7909.2008.00669.x

Department of Energy and Mining, Regional Directorate Beni Mellal, Le gisement de fer d'Ait Amar, pp. $1-5$

Dudka S., Piotrowska M., Chlopeckca A., Witek T., 1995. Trace metal contamination of soils and crop plants by the mining and smelting industry in Upper Silesia, South Poland. Journal of Geochemical Exploration, 5, p. 237-250. http://dx.doi.org/10.1016/0375-6742(94)00047-F

Díez Lázaro J., Kidd P. S., Monterroso Martínez C., 2006. A phytogeochemical study of the Trás-os-Montes region (NE Portugal): Possible species for plant-based soil remediation technologies. Science of the Total Environment, 354, p. 265-277.

http://dx.doi.org/10.1016/j.scitotenv.2005.01.001

EUROPEAN COMMON (Commission of the European Communities) Council directive of 12 June 1986 on the protection of the environment and in particular of the soil, when sewage sludge is used in agriculture, Official $\mathbf{J}$ European Communities 1986; L181 (86/278/EEC):6 -12.

FAOUN (Food and Agriculture Organization of the United Nations) Physical and chemical methods of soil and water analysis, Soils Bulletin, 10 (1984), pp. 1-275

Freitas H., Prasad M. N. V., Pratas J., 2004. Plant community tolerant to trace elements growing on the degraded soils of São Domingos mine in the south east of Portugal: environmental implications. Environment International, 30, p. 65-72.

http://dx.doi.org/10.1016/S0160-4120(03)00149-1

Ghosh E, Singh S.P. 2005a. A review on phytoremediation of heavy metals and utilization of its byproducts, Applied Ecology and Environmental Research 3(1), p. 1-18.

Ghosh M, Singh S.P. 2005b. A comparative study of cadmium phytoextraction by accumulator and weed species, Environmental Pollution 133, p. 365-371

http://dx.doi.org/10.1016/j.envpol.2004.05.015

Grant C. A., Clarke J. M., Duguid S., Chaney R. L., 2008. Selection and breeding of plant cultivars to minimize cadmium accumulation, Sciences of the Total Environment, 390, p. 301-310.

http://dx.doi.org/10.1016/j.scitotenv.2007.10.038

Gupta S.K., Vollmer M.K., Krebs R., 1996. The importance of mobile, mobilisable and pseudo total heavy metal fractions in soil for three-level risk assessment and risk management. Science of the Total Environment 178, p. 11-20. http://dx.doi.org/10.1016/0048-9697(95)04792-1

Ha N. T. H., Sakakibara M., Sano S., Nhuan M. T., 2011. Uptake of metals and metalloids by plants growing in a lead-zinc mine area, Northern Vietnam, Journal of Hazardous Materials, 186, p. 1384-1391

http://dx.doi.org/10.1016/j.jhazmat.2010.12.020

Harris J.A, Birch P., Palmer J.P. Land restoration and reclamation, Principles and practice. London: Longman; 1996.

Horsfall J. R. M., Abia A. A., 2003. Sorption of cadmium (II) and zinc (II) ions from aqueous solution by cassava waste biomass (Manihot sculenta cranz). Water Research, 37, p. 4913-4923.

http://dx.doi.org/10.1016/j.watres.2003.08.020

Horsfall M., Spiff A., 2005. Effect of temperature on the sorption of $\mathrm{Pb} 2+$ and $\mathrm{Cd} 2+$ from aqueous solution by caladium bicolor (wild cocoyam) biomass, Electronic Journal of Biotechnology [Online: accessed 20th January 2012], 8(2), Available from Internet: /http://www.ejbiotechnology.info/content/vol8/issue2/4/inde x.htmlS. ISSN: 0717-3458.

Houba V.J.G., Novozamsky I., Lexmond T.M., VanDer-Lee J.J. 1990, Applicability of $0.01 \mathrm{M} \mathrm{CaCl} 2$ as a single extraction solution for the assessment of the nutrient status of soils and other diagnostic purposes, Communications in Soil Science and Plant Analysis, 21, p. 2281-2290.

http://dx.doi.org/10.1080/00103629009368380 
Houba V.J.G., Lexmond T.M., Novozamsky I., Van Der Lee J.J. 1996. State of the art and future developments in soil analysis for bioavailability assessment. Science of the Total Environment, 178, p. 21-28.

http://dx.doi.org/10.1016/0048-9697(95)04793-X

Igwe J. C., Abia A. A., 2006. A bioseparation process for removing heavy metals from wastewater using biosorbents, African Journal of Biotechnology, 5, p. 11671179

Kabata-Pendias A., Pendias H., 1992. Trace elements in soils and plants, 2nd Edition. CRC press, Boca Raton, FL, pp.:365.

Kisku G.C., Pandey P., Negi M.P., Misra V. (2011) Uptake and accumulation of potentially toxic metals $(\mathrm{Zn}$, $\mathrm{Cu}$ and $\mathrm{Pb}$ ) in soils and plants of Durgapur industrial belt, Journal of Environmental Biology 32 (6): 831-8.

PMid:22471223

Lasat M. M., 2000. Phytoextraction of metals from contaminated soil: a review of plant/soil/metal interaction and assessment of pertinent agronomic issues. Journal of Hazardous Substance Research, 2, p. 1-25.

Lasat M. M., 2002.Phytoextraction of toxic metals, a review of biological mechanisms. Journal of Environmental Quality, 31, p. 109-120.

http://dx.doi.org/10.2134/jeq2002.0109

Lorestani B., Cheraghi M., Yousefi N., 2011 Accumulation of $\mathrm{Pb}, \mathrm{Fe}, \mathrm{Mn}, \mathrm{Cu}$ and $\mathrm{Zn}$ in plants and choice of hyperaccumulator plant in the industrial town of vian, Iran Archives of Biological Sciences, Belgrade, 63 (3), p. $739-745$.

http://dx.doi.org/10.2298/ABS1103739L

MA L. Q., DONG Y., 2004 Effects of incubation on solubility and mobility of trace metals in two contaminated soils. Environmental Pollution, 130, p. 301-307. http://dx.doi.org/10.1016/j.envpol.2004.01.007

Malik, N., Biswas, A.K., 2012. Role of higher plants in remediation of metal contaminated sites. Scientific Reviews and Chemical Communications, 2, p. 141-146.

Mattina M. I., Lannucci-Berger W., Musante C., White J. C., 2003 Concurrent plant uptake of heavy metals and persistent organic pollutants from soil, Environmental Pollution, 124(3), p. 375-378

http://dx.doi.org/10.1016/S0269-7491(03)00060-5

Mcgrath S. P And ZHAO F. J., 2003 Phytoextraction of metals and metalloids from contaminated soils, Current Opinion in Biotechnology, 14(3), p. 277-282. http://dx.doi.org/10.1016/S0958-1669(03)00060-0

Moreno-Jimenez E., Penalosa J. M., Manzano R., Carpena-Ruuiz R. O., Gamarra R., Esteban E., 2009. Heavy metals distribution in soils surrounding an abandoned mine In NW Madrid (Spain) and their transference to wild flora. Journal of Hazardous Materials, 162, p. 854-859. http://dx.doi.org/10.1016/j.jhazmat.2008.05.109

Nagajyoti P. C., Lee K. D., Sreekanth T. V. M., 2010. Heavy metals, occurrence and toxicity for plants: a review. Environmental Chemistry Letters, 8, p. 199-216.

http://dx.doi.org/10.1007/s10311-010-0297-8

NEN 5704, 1996, Soil-Sample preparation of soil Extraction with a calcium chloride solution $(0.01 \mathrm{~mol} / \mathrm{L}) 4 \mathrm{p}$

Pérez-De-Mora A., Burgos P., Madejón E., Cabrera F., Jaeckel P., Schloter M., 2006. Microbial community structure and function in a soil contaminated by heavy metals: effects of plant growth and different amendments. Soil Biology and Biochemistry38, p. 327-341. http://dx.doi.org/10.1016/j.soilbio.2005.05.010

Pueyo M., López-Sanchez J.F., Rauret G., 2004 Assessment of $\mathrm{CaCl} 2, \mathrm{NaNO} 3$ and $\mathrm{NH} 4 \mathrm{NO} 3$ extraction procedures for the study of $\mathrm{Cd}, \mathrm{Cu}, \mathrm{Pb}$ and $\mathrm{Zn}$ extractability in contaminated soils. Analytica Chimica Acta 504, p. 217226 http://dx.doi.org/10.1016/j.aca.2003.10.047

Raghothama K. G., Karthikeyan A. S., 2005. Phosphate acquisition, Plant and Soil, 274, 37-49

http://dx.doi.org/10.1007/s11104-004-2005-6

Raskin L., Smith R. D., Salt D. E., 1997, Phytoremediation of metals: using plants to remove pollutants from the environment. Current Opinion in Biotechnology, 8, p. 221-226.

http://dx.doi.org/10.1016/S0958-1669(97)80106-1

Remon E., Bouchardon J. L., Cornier B., Guy B., Leclerc J. C., Faure O., 2005. Soil characteristics, heavy metal availability and vegetation recovery at a former metallurgical landfill: Implications in risk assessment and site restoration. Environmental Pollution, 137, p. 316-323. http://dx.doi.org/10.1016/j.envpol.2005.01.012

Rio M. D., Font R., Almela C., Velez D., Montoro R., Bailon A. D. H., 2002. Heavy metals and arsenic uptake by wild vegetation in the Guadiamar river area after the toxic spill of the Aznalcollar mine, Journal of Biotechnology, 98, p. 125-137.

http://dx.doi.org/10.1016/S0168-1656(02)00091-3

Schachtman D. P., Reid R. J., Ayling S. M., 1998, Phosphorus Uptake by Plants: From Soil to Cell, Plant Physiology, 116, p. 447-453.

http://dx.doi.org/10.1104/pp.116.2.447

Shen J., Yuan L., Zhang J., Li H., Bai Z., Chen X., Zhang W, Zhang F., 2011. Phosphorus Dynamics: From Soil to Plant. Plant Physiology, 156, p. 97-1005.

http://dx.doi.org/10.1104/pp.111.175232

Stoltz E., Greger M., 2002. Accumulation properties of $\mathrm{As}, \mathrm{Cd}, \mathrm{Cu}, \mathrm{Pb}$, and $\mathrm{Zn}$ by four wetland plant species growing on submerged mine tailings, Environmental and Experimental Botany, 47, p. 271-280.

http://dx.doi.org/10.1016/S0098-8472(02)00002-3

Unterbrunner R., Wieshammer G., Hollender U., Felderer B., Wieshammer-Zivkovic M., Puschenreiter M., Wenzel, W. W., 2007, Plant and fertiliser effects on rhizodegradation of crude oil in two soils with different nutrient status. Plant and Soil, 300 (1-2), p. 117-126. http://dx.doi.org/10.1007/s11104-007-9394-2

Venditti D., Durécu S., Berthelin J., 2000. A multidisciplinary approach to assess history, environmental risks and remediation feasibility of soils contaminated by metallurgical activities, Part A: chemical and physical properties of metals and leaching ability. Archives of Environmental Contamination and Toxicology, 38, p. 411420.

http://dx.doi.org/10.1007/s002449910055

Walker D.J., Clemente R., Roig A., Bernal M.P., 2003. The effects of soil amendments on heavy metal bioavailability in two contaminated Mediterranean soils. Environmental Pollution 122, p. 303-312. http://dx.doi.org/10.1016/S0269-7491(02)00287-7

Walkley A. And Black I. A., 1934. An examination of Degtjareff method for determining organic carbon in soils: effect of variations in digestion conditions and of inorganic soil constituents. Soil Sciences 63, p. 251-263 http://dx.doi.org/10.1097/00010694-194704000-00001

Wei S., Zhou Q., 2008. Trace elements in agroecosystems. In: Prasad MNV, ed. Trace Elements as contaminants and nutrients-Consequences in Ecosystem and Human Health. Hoboken, NJ: Wiley, pp.: 55-80. http://dx.doi.org/10.1002/9780470370124.ch3

Wong M. H., 2003, Ecological restoration of mine degraded soils, with emphasis on metal contaminated soils. Chemosphere, 50(6), p. 775-780.

http://dx.doi.org/10.1016/S0045-6535(02)00232-1

Wu F. B., Zhang G. P., 2002. Genotypic variation in kernel heavy metal concentrations in barley and as affected by soil factors, Journal of Plant Nutrition, 25, p. 1163-1173 
Yoon J., Cao X., Zhou Q., Ma L. Q., 2006. Accumulation of $\mathrm{Pb}, \mathrm{Cu}$, and $\mathrm{Zn}$ in native plants growing on a contaminated Florida site, Science of the Total Environment, 368, p. 456-464.

http://dx.doi.org/10.1016/j.scitotenv.2006.01.016

Zhao F. J., Hamon R. E., Lombi E., Mclaughlin M. J., Mcgrath S. P., 2002, Characteristics of cadmium uptake in two contrasting ecotypes of the hyperaccumulator Thlaspi caerulescens. Journal of Experimental Botany, 53, p. 535543.

http://dx.doi.org/10.1093/jexbot/53.368.535

Mohamed NOURI - PhD student of the Laboratory of management and valorization of natural resources, Team of Genetic and Plant Biotechnology, Faculty of Science and Techniques, University of Sultan Moulay Slimane, Beni-Mellal, Morocco.

Main research area: Genetic Plant Biotechnology

Address: University of Sultan Moulay Slimane, Faculty of Sciences and Technics, B.P 523, 23000 Beni-Mellal, Morocco.

E-mail: mohamednouri35@gmail.com

Tel: $+212669104395$

Fernando Gonçalves- researcher of the CESAM \& Department of Biology, University of Aveiro, Campus Universitário de Santiago. Main research area: Ecology, Ecotoxicology

Address: Department of Biology, University of Aveiro, Campus Universitário de Santiago, 3810-193 Aveiro, Portugal

E-mail:_fjmg@ua.pt

Tel: $\quad+351234370777$

Jausé Paulo Sousa - researcher of the IMAR-CMA, Department of Life Sciences, University of Coimbra.

Main research area: Ecology, Ecotoxicology

Address: EC University of Coimbra 3001-401 Coimbra, Portugal

E mail: $\quad$ jps@zoo.uc.pt

Tel: $\quad+351239855774$
Jörg Römbke - researcher of the ECT Oekotoxikologie GmbH, Flörsheim, Germany.

Main research area: Ecotoxicology, Biodiversity

Address: Boettgerstr. 2-14 65439 Floersheim/Main Germany

E-mail: j-roembke@ect.de

Tel: $\quad+49-6145-956450$

Mohamed Ksibi - researcher of the Laboratory Water, Energy and Environment, University of Sfax, Tunisia.

Main research area: Environmental Biotechnology

Address: $\quad$ ISBS BP 261, 3038 road of Soukra km 4.5 Sfax

E-mail: mdh.ksibi@gmail.com

Tel: $\quad+21674674354$

Ruth Pereira - researcher of the Department of Biology of the Faculty of Sciences of the University of Porto, Porto \& CESAM,

University of Aveiro, Portugal.

Main research area: Ecology, Ecotoxicology

Address: Department of Biology of the Faculty of Sciences of

E-mail: the University of Porto, Portugal

Tel: $\quad+351234370773$

Abdelmajid Haddioui - researcher of the Laboratory of management and valorization of natural resources, Team of Genetic and Plant Biotechnology, Faculty of Science and Techniques, University of Sultan Moulay Slimane, Beni-Mellal, Morocco

Main research area: Genetic, Plant Biotechnology

Address: University of Sultan Moulay Slimane, Faculty of Sciences and Technics, B.P 523, 23000 Beni-Mellal, Morocco.

E mail: ahaddioui@yahoo.fr

Tel: $\quad+212661684239$ 


\title{
Savaiminis metalų ir fosforo sunaudojimas vegetacijos metu apleistose centrinio Maroko metalo rūdos Semiarid kasyklose: vertinimas taikant fitoekstarkcijos metodą
}

\author{
Mohamed Nouri ${ }^{1}$, Fernando Gonçalves ${ }^{2}$, Jausé Paulo Sousa ${ }^{3}$, Jörg \\ Römbke $^{4}$, Mohamed Ksibi ${ }^{5}$, Ruth Pereira ${ }^{6}$, Abdelmajid Haddioui ${ }^{1}$ \\ ${ }^{1}$ Gamtiniu ištekliu vertinimo ir valdymo laboratorija, Genetikos ir augalu biotechnologijos grupe, Mokslo ir \\ technologijufakultetas, Sultan Moulay Slimane universitetas, Marokas \\ ${ }^{2}$ Biologijos katedra, Aveiro universitetas, Portugalija \\ ${ }^{3}$ Gamtos mokslu katedra, Coimbra universitetas, Portugalija \\ ${ }^{4}$ ECT Oekotoxikologie GmbH, Vokietija \\ ${ }^{5}$ Vandenu, energetikos ir aplinkos laboratorija, Sfakso universitetas, Tunisas \\ ${ }^{6}$ Biologijos katedra, Mokslu fakultetas, Porto universitetas, Portugalija
}

(gauta 2012 m. kovo mèn., priimta spaudai 2013 m. birželio mèn.)

Straipsnyje analizuoti savaime augantys vietiniai augalai (atstovaujantys 12 rūšių, 10 genčių ir 3 šeimas), siekiant įvertinti $\mathrm{Cd}, \mathrm{Cr}, \mathrm{Cu}, \mathrm{Zn}, \mathrm{Pb}, \mathrm{Fe}$ ir $\mathrm{P}$ akumuliaciją ūgliuose ir šaknyse. Ait Amar metalo rūdos kasykloje surinktos skirtingos augalų rūšys turejjo skirtingas metalų sankaupas ūgliuose ir šaknyse. Iš žolinių augalų (Apiaceae, Asteraceae ir Poaceae) didžiausios $\mathrm{Cd}, \mathrm{Cu}, \mathrm{Zn}$ stiebuose nustatytos Echinops spinosus L (0,989 29,190 ir 175,347 $\left.\mathrm{mg} \mathrm{Kg}^{-1}\right)$, Cr Cladanthus arabicus (L) Class $\left(9,241 \mathrm{mg} \mathrm{Kg}^{-1}\right)$, o $\mathrm{Pb}$, Fe ir $\mathrm{P}$ - Leontodon hispidilus (Delile) Boiss (5,952, 1522,839 ir $4612,795 \mathrm{mg} \mathrm{Kg}^{-1}$ ) augaluose. Didžiausias Zn biokoncentracijos veiksnys nustatytas E. spinosus $L(1,68)$. Didžiausias pasisavinimo iš dirvos veiksnys: Cd - Stipa Capensis thumb $(1,24), \mathrm{Cr}-C$. arabicus (L) Class $(2,01), \mathrm{Cu}-$ Carthamus lanatus $L(8,40), \mathrm{Zn}-$ E. spinosus $L$ (2,52), Pb - Eryngium ilicifolium Lam (7,00), P - E. ilicifolium Lam (537,72), Fe - L. hispidilus (Delile) Boiss $(0,52)$. E. spinosus L pasižymèjo didžiausiu Zn fitoekstrakcijos laipsniu, o kiti augalai gebejjo gerai augti metalais užterštose teritorijose, pasisavindami tik mažas metalų koncentracijas, todèl jie gali būti laikomi gerais fitostabilizatoriais. 